\title{
BMJ Global Health Equity and expertise in the UN Food Systems Summit
}

\author{
Nicholas Nisbett (D) , ${ }^{1}$ Sharon Friel (D) , ${ }^{2}$ Richmond Aryeetey (D) , ${ }^{3}$ \\ Fabio da Silva Gomes, ${ }^{4}$ Jody Harris (1) , ${ }^{1,5}$ Kathryn Backholer (iD , 6 \\ Phillip Baker (D) , ${ }^{7}$ Valarie Blue Bird Jernigan (D), ${ }^{8}$ Sirinya Phulkerd (D) ${ }^{9}$
}

To cite: Nisbett N, Friel S, Aryeetey R, et al. Equity and expertise in the UN Food Systems Summit. BMJ Global Health 2021;6:e006569. doi:10.1136/ bmjgh-2021-006569

Received 9 June 2021 Accepted 11 June 2021

Check for updates

C Author(s) (or their employer(s)) 2021. Re-use permitted under CC BY-NC. No commercial re-use. See rights and permissions. Published by BMJ.

For numbered affiliations see end of article.

Correspondence to Dr Nicholas Nisbett; N.Nisbett@ids.ac.uk
The UN Food Systems Summit is expected to launch bold new actions, solutions and strategies to deliver progress on all 17 sustainable development goals (SDGs), each of which requires a transformation in the way the world produces, consumes and thinks about food. However, the summit preparations have started controversially, with claims of corporate capture by prominent civil society groups, ${ }^{1}$ who, alongside the current and two former UN Special Rapporteurs on the Right to Food, ${ }^{2}$ have also noted insufficient attention paid to human rights and to rebalancing power in the food system itself.

The issue of corporate capture is an important one for the summit. Early decisions to implement a clear set of rules on corporate participation and transparency were missed and need rectifying urgently for the summit to continue with any legitimacy, as the UN Special Rapporteurs and the scientists of a new boycott ${ }^{3}$ have pointed out. The summit has embraced the (contested, ${ }^{4}$ some would argue failed $)^{5}$ principle of 'multistakeholder inclusivity' as essential for the summit to be a 'safe space' for all actors, but with little regards to how power asymmetries between stakeholders within the summit itself must be acknowledged, addressed and accounted for transparently; not a helpful precedent for a global architecture to address those same power asymmetries.

Closely linked to these issues have been the role of right-based and equity-based approaches within the summit; and how far the summit's 'forum' shifts away from the UN Committee on Food Security, where these issues have a strong mandate, risks diluting hard won battles for a fairer, more just and right-based food system. ${ }^{5}$ The summit hopes to contribute to the promise global leaders signed at the SDG summit to 'leave no one behind'. Equity is, therefore, at the heart of the summit. However,
Summary box

- The UN Food Systems Summit is bold but controversial, with important implications for global food systems and public health.

- Alongside claims of corporate capture, many have noted insufficient attention paid to human rights and to rebalancing power in the food system.

- These issues speak to wider issues of participation and equity in the summit itself. Narrow definitions of equity only consider income inequities in outcomes and coverage. Broader definitions consider why such inequities persevere and are interlinked via processes that can be historical and intergenerational.

- The summit's science group is slanted in disciplinary expertise: it lacks sufficient expertise in equity, health, noncommunicable diseases or representatives with expertise in indigenous knowledge.

- It is not too late to rectify this in the summit structures, as we approach the September summit meeting.

without advancing both a stronger normative and multidisciplinary understanding of equity, the summit process risks missing a once in a generation chance to refocus understanding and action on food system inequity. Attention ought to be drawn not only to the current inequitable experiences and outcomes facing people within food systems but also to the reasons why such inequities in outcomes persevere (eg, nonwhite households were two times as likely to face food insecurity during the COVID-19 pandemic compared with white British households; and those with disability or health problems, three times more likely). ${ }^{6}$ We wonder what egregious failings of political systems are being glossed over in 'leave no one behind' if such virtuous aspiration leads to a failure to ask questions of why so many people, for so long, have been 'held back'.

The problem is partly with the concept of equity itself: incontrovertibly, a good thing 
to pursue, but variously defined. For example, among experts on chronic undernutrition, equity is often conceptualised as diverging coverage of health interventions or outcomes differing by socioeconomic groups. ${ }^{7}$ Among experts on health equity and diet-related noncommunicable diseases, however, equity often also refers more to the structural, social and commercial determinants of health and the concentration of power among private sector interests. ${ }^{8}$

Summit participants are tasked with proposing and prioritising a set of 'game changing solutions' for member states to adopt. To some equity experts, such solutions might mean providing significantly scaled up child and maternal health services, particularly targeted at marginalised communities; or similar access to systems of social protection or food assistance. Equity to others might also mean finding ways to tackle historical injustices that still shape people's lives. For example, dispossessing communities, particularly indigenous peoples, from ancestral lands-and the culinary and agroecological skills and knowledge that adhere to those territories-has been devastating to local food systems. Public health then comes to mean something quite different: regaining sovereignty and control over land and food as part of wider self-determination; working to preserve or return to traditional and healthy foods and associated culinary practices against a tidal wave of ultraprocessed, nontraditional and unhealthy products. ${ }^{9}$

Separate (but in our view, still complementary) understandings of equity also reflect the siloed and hierarchical knowledge systems that still frame the UN system and similar international architectures. Tackling growing uncertainties that range from pandemics, to climate change, to intractable historical food-based problems 'require a fundamental rethinking of how expertise of multiple sorts and new forms of professionalism are convened and combined'. ${ }^{10} 11$ The scientific committee of the UNFSS is dominated by agricultural economists and natural scientists: great scholars, but a missed opportunity to encounter knowledge not only from experts in health equity or gender and rights but also from indigenous and other traditional people (not those speaking for them), food workers and others with lived experience of malnutrition and diet-related diseases. We do see these voices represented elsewhere in the summit (sometimes marginally), but the summit's approach to filling its scientific committee feels outdated for a summit concerned with food systems, when most systems experts already recognise the need for this diversity of knowledge and experience.

The structure of the summit itself also adds another layer of inequity and imbalance of power. There are many ways to get involved in the summit, and in principle this is positive. But Member States or civil society organisation with limited resources will not be able to become a Food Systems Hero, help to raise awareness of food systems on social media, host or join a Dialogue and also participate and follow all five Action Tracks. Those with greater resources, and their propositions, will then reign. For this reason, the myriad of participation mechanisms is not as important as how this will be weighed into decisions; to return to the initial concerns with the summit, how will the power of those actors opposing healthier, more sustainable and more equitable food systems be constrained?

As we write in June, ahead of a September Summit, time is not late to take action in rebalancing powers and enabling a greater diversity of knowledge, not simply among a multiplicity of voices in multiple public forums, but explicitly engaged at the summit's top table of expertise and summit leadership. It is also not late to adopt mechanisms that limit the engagement of those actors whose primary interests have driven our food systems to become unhealthy, unsustainable and inequitable, so the voices of the people can be clearly heard. Doing so would help meet the need for putting equity-focused action at the heart of the summit in a way that accords with the existing UN legal framework on rights and the SDGs; and with the multiple traditions of equity, we argue, need to be embraced for the summit to be a success on its own terms.

\section{Author affiliations}

${ }^{1}$ Health and Nutrition Research Cluster, Institute of Development Studies at the University of Sussex, Brighton, UK

${ }^{2}$ Menzies Centre for Health Governance, School of Regulation and Global Governance, Australian National University, Canberra, Australian Capital Territory, Australia

${ }^{3}$ School of Public Health, University of Ghana, Accra, Ghana

${ }^{4}$ Pan American Health Organization, Washington, District of Columbia, USA

${ }^{5}$ Healthy Diets Flagship, World Vegetable Centre, Bangkok, Thailand

${ }^{6}$ Institute for Health Transformation, Deakin University, Geelong, Victoria, Australia

${ }^{7}$ Institute for Physical Activity and Nutrition, Deakin University, Melbourne, Victoria, Australia

${ }^{8}$ Center for Indigenous Health Research and Policy, Oklahoma State University, Tulsa, Oklahoma, USA

${ }^{9}$ Institute for Population and Social Research, Mahidol University, Nakhon Pathom, Thailand

Twitter Phillip Baker @philbakernz

Contributors All authors contributed to this commentary.

Funding The authors have not declared a specific grant for this research from any funding agency in the public, commercial or not-for-profit sectors.

Competing interests Nicholas Nisbett is a member of the UNFSS Action Track 4 Leadership Group. Dr. Nisbett declares previous funding from the Bill and Melinda Gates Foundation, India; the International Food Policy Research Institute and UK Research and Innovation. Dr Backholer declares previous funding from the National Heart Foundation of Australia. The views expressed here are that of the authors alone.

Patient consent for publication Not required.

Provenance and peer review Not commissioned; internally peer reviewed.

Data availability statement All data relevant to the study are included in the article.

Open access This is an open access article distributed in accordance with the Creative Commons Attribution Non Commercial (CC BY-NC 4.0) license, which permits others to distribute, remix, adapt, build upon this work noncommercially, and license their derivative works on different terms, provided the original work is properly cited, appropriate credit is given, any changes made indicated, and the use is non-commercial. See: http://creativecommons.org/ licenses/by-nc/4.0/. 


\section{ORCID iDs}

Nicholas Nisbett http://orcid.org/0000-0002-9558-2263

Sharon Friel http://orcid.org/0000-0002-8345-5435

Richmond Aryeetey http://orcid.org/0000-0003-4667-592X

Jody Harris http://orcid.org/0000-0002-3369-1253

Kathryn Backholer http://orcid.org/0000-0002-3323-575X

Phillip Baker http://orcid.org/0000-0002-0802-2349

Valarie Blue Bird Jernigan http://orcid.org/0000-0002-3965-8518

Sirinya Phulkerd http://orcid.org/0000-0001-9373-3120

\section{REFERENCES}

1 Main concerns of CSM Letter on Food System Summit remain without adequate response. Note of the CSM liaison group after meeting with CFS chair and special Envoy for UN food system Summit (UNFSS). Civil Society and Indigenous peoples' mechanism for relations with the un Committee on world food security. Available: http://www.csm4cfs.org/14647/ [Accessed 26 Mar 2021].

2 The UN Food Systems Summit: How Not to Respond to the Urgency of Reform. Michael Fakhri, Hilal Elver and Olivier de Schutter. Available: https://grain.org/en/article/6639-the-un-food-systemssummit-how-not-to-respond-to-the-urgency-of-reform [Accessed 23 Mar 2021].

3 Agroecology Research-Action Collective. Scientists boycott the 2021 un food systems Summit, 2021. Available: https://agroecologyr esearchaction.org/scientists-boycott-the-2021-un-food-systemssummit/

4 HLPE. Multi-Stakeholder partnerships to finance and improve food security and nutrition in the framework of the 2030 agenda. Rome: A report by the High Level Panel of Experts on Food Security and Nutrition of the Committee on World Food Security, 2018.

5 Canfield M, Anderson MD, McMichael P. Un food systems Summit 2021: dismantling democracy and resetting corporate control of food systems. Front Sustain Food Syst 2021;5.

6 A crisis within a crisis: the impact of Covid-19 on household food security insights from food Foundation surveys on how the pandemic has affected food access in the UK (March 2020 to January 2021). Available: https://foodfoundation.org.uk/wp-content/ uploads/2021/03/FF_Impact-of-Covid_FINAL.pdf

7 Victora CG, Christian P, Vidaletti LP, et al. Revisiting maternal and child undernutrition in low-income and middle-income countries: variable progress towards an unfinished agenda. Lancet 2021;397:1388-99.

8 Marmot M, Friel S, Bell R, et al. Closing the gap in a generation: health equity through action on the social determinants of health The Lancet 2008;372:1661-9.

9 Blue Bird Jernigan V. Indigenous food Sovereignty in public health. (in process)

10 Horton R. Offline: COVID-19 is not a pandemic. Lancet 2020;396:874.

11 Leach M, MacGregor H, Scoones I, et al. Post-pandemic transformations: how and why COVID-19 requires us to rethink development. World Dev 2021;138:105233. 